\title{
POSTZALEŻNOŚCIOWE NARRACJE PATRIOTYCZNE W WYBRANYCH TEKSTACH DOROTY MASŁOWSKIEJ, DAWIDA BIEŃKOWSKIEGO I IGNACEGO KARPOWICZA
}

\author{
AGATA LEWANDOWSKA ${ }^{1}$ \\ (Uniwersytet im. A. Mickiewicza w Poznaniu)
}

Słowa kluczowe: polska literatura najnowsza, dyskurs postzależnościowy, patriotyzm, tożsamość narodowa, Dawid Bieńkowski, Ignacy Karpowicz, Dorota Masłowska

Key words: Polish contemporary literature, post-dependent discourse, patriotism, national identity, Dawid Bieńkowski, Ignacy Karpowicz, Dorota Masłowska

\begin{abstract}
Abstrakt: Agata Lewandowska, POSTZALEŻNOŚCIOWE NARRACJE PATRIOTYCZNE W WYBRANYCH TEKSTACH DOROTY MASŁOWSKIEJ, DAWIDA BIEŃKOWSKIEGO I IGNACEGO KARPOWICZA. „PORÓWNANIA” 12, 2013, T. XII, s. 73-85. ISSN 1733-165X. Celem artykułu jest próba zastanowienia się nad tym, czy na narracje patriotyczne pojawiające się w wybranych powieściach Doroty Masłowskiej (Woja polsko-ruska pod flaga biało-czerwona), Dawida Bieńkowskiego (Biało-czerwony) i Ignacego Karpowicza (Niehalo) można spojrzeć jako na narracje postzależnościowe/postkolonialne. Każdy z omawianych tekstów podnosi problem współczesnego polskiego patriotyzmu, a między ojczyźnianymi narracjami rozwijanymi przez bohaterów poszczególnych powieści dostrzec można pewne znaczące paralele, mogące świadczyć właśnie o postzależnościowym statusie uobecniającego się w polskiej literaturze najnowszej dyskursu patriotycznego. Do tych cech wspólnych należą przede wszystkim: tendencja do definiowania własnej narodowej tożsamości w opozycji do kolektywnego wroga (zarówno „zewnętrznego", jak i „wewnętrznego"), sytuowanie opowieści o obronie tożsamości zbiorowej w przestrzeni wojennej, skłonność do rekompensowania zinternalizowanego poczucia poniżenia za pomocą narodowej megalomanii czy poszukiwanie esencji polskości i źródła narodowej metanarracji $\mathrm{w}$ czasach przedrozbiorowych. Pod koniec tekstu namysłowi poddane zostaje również to, dlaczego współczesne literackie reprezentacje dyskursu patriotycznego korzystają ze zbliżonych schematów, powielając i utrwalając przywoływane stereotypy.
\end{abstract}

\footnotetext{
${ }^{1}$ Correspondence Address: a.lewando@wp.pl
} 


\begin{abstract}
Agata Lewandowska, POST-DEPENDENT PATRIOTIC NARRATIVES IN SELECTED TEXTS BY DOROTA MASŁOWSKA, DAWID BIEŃKOWSKI AND IGNACY KARPOWICZ. "PORÓWNANIA" 12, 2013, Vol. XII, p. 73-85. ISSN 1733-165X. This article is an attempt at reflecting on whether patriotic narratives that appear in selected novels of Dorota Masłowska (Wojna polsko-ruska pod flaga biało-czerwona), Dawid Bieńkowski (Biało-czerwony) and Ignacy Karpowicz (Niehalo) can be seen as post-dependent / postcolonial. Each of these texts raises the problem of contemporary Polish patriotism. Some significant parallels can be observed between the homeland narratives developed by characters in particular novels. These parallels can be the evidence of the post-dependent status of patriotic discourse represented in the newest Polish literature. The main characteristics shared by the narratives are: the tendency to define national identity in opposition to the collective enemy (both "external" and "internal"), presenting the problem of the defense of collective identity by using the war scheme, the tendency to compensate the internalized sense of humiliation by using national megalomania and searching for the essence of Polish identity and the source of national meta-narrative in the pre-partition era. At the end of the text it is also discussed why contemporary literary representations of patriotic discourse use similar schemes, duplicating and consolidating the stereotypes that they refer to.
\end{abstract}

"Jeżeli z czym pragnąłbym bić się, to z Ojczyzną - o moją ludzką wartość"2 pisał w Dzienniku Witold Gombrowicz, największy chyba, choć nie jedyny, z dwudziestowiecznych krytyków tradycyjnego dyskursu polskości. Dyskurs ów spotkał się wszakże z dezaprobatą wielu wybitnych literatów ubiegłego stulecia: ganił go Czesław Miłosz, piętnował Andrzej Bobkowski, bezlitośnie wyszydzał Sławomir Mrożek ${ }^{3}$. Krytyczny namysł nad jego przesłaniem staje się także udziałem wielu autorów tworzących scenę literacką dwudziestego pierwszego wieku, a pisarstwo Doroty Masłowskiej, Dawida Bieńkowskiego i Ignacego Karpowicza jest tego przykładem. W niniejszym tekście podejmę próbę analizy patriotycznych narracji ukazanych w Wojnie polsko-ruskiej pod flaga biało-czerwona (2002) Masłowskiej, Niehalo (2006) Karpowicza oraz Biato-czerwonym (2007) Bieńkowskiego4, starając się wykazać, iż narracje te uznać można za postzależnościowe czy postkolonialne. Spojrzenie na to, w jaki sposób artykułowana jest współcześnie polskość z perspektywy proponowanej przez studia postkolonialne wydaje się niebezzasadne. Korzenie dzisiejszego dominującego dyskursu patriotycznego bez wątpienia sięga-

2 W. Gombrowicz, Dziennik 1953-1956. Kraków 1988, s. 163.

${ }^{3}$ Wśród literatury przedmiotu podejmującej temat literackich konwersacji z mitem romantycznym warto przywołać chociażby: M. Piwińska, Legenda romantyczna i szydercy. Warszawa 1973 i L. Burska Kłopotliwe dziedzictwo. Szkice o literaturze i historii. Warszawa 1998.

${ }^{4}$ Oprócz tego, iż teksty owe są zgodne na poziomie badanego tematu, o ich doborze zadecydował także fakt, że daty ich wydania dzieli stosunkowo niewielka rozpiętość czasowa (pięć lat), operują podobną groteskową poetyką deformującą i przejaskrawiającą rzeczywistość, jak również to, że ich autorzy zdają się dzielić zbliżony światopogląd oraz prezentować podobne zaangażowanie społeczne. 
ją okresu, w którym Polska pełniła rolę quasi-kolonii, kształt nadały mu zaś rozmaite, traumatyczne najczęściej, doświadczenia okresu długotrwałej zależności. Przez sto dwadzieścia trzy lata zaborów, pięć lat wojny i niespełna pół wieku zależności od Związku Radzieckiego romantyczny wzorzec postawy patriotycznej zdążył na tyle silnie zakorzenić się w wyobraźni zbiorowej Polaków, iż wiele wskazuje na to, że nawet $\mathrm{w}$ czasach niezależności politycznej w obszarze dominującego dyskursu ojczyźnianego niedużo się zmieniło. Dyskurs ów pozostaje przestrzenią, w której romantyczny paradygmat wciąż jawi się jako ważny i nośny, mimo iż - jak prognozowała na początku lat dziewięćdziesiątych Maria Janion - wydawałoby się, że w nowej sytuacji społeczno-kulturowo-politycznej ulegnie on wyraźnemu osłabieniu, a być może nawet dezaktualizacji ${ }^{5}$.

Prowadząc rozważania na temat literackich reprezentacji współczesnego polskiego dyskursu patriotycznego należałoby postawić kilka pytań: czy nadal jest to dyskurs, którego prymarną funkcję stanowi łączenie wspólnoty narodowej, czy raczej przyczynia sie on do powstawania $\mathrm{w}$ społeczeństwie podziałów? W jakim stopniu jest to język neutralny politycznie, a w jakim narzędzie manipulowania zbiorowymi emocjami? Jaka jest rola patriotyzmu w suwerennym społeczeństwie, które nie musi już chronić tożsamości zbiorowej przed obcą agresją? W końcu, czy jakikolwiek dyskurs patriotyczny ma rację bytu w europejskiej przestrzeni dążącej do multikulturowości i, jeżeli tak, to na jakich prawach może funkcjonować? Wydaje się, że podobne pytania formułują powieści Masłowskiej, Karpowicza i Bieńkowskiego. Każdy z omawianych tekstów oświetla problem patriotyzmu nieco inaczej, wyostrza inne jego aspekty, bierze pod lupę odmienne elementy. Zawarte w nich narracje ojczyźniane łączy jednak kilka znamiennych cech, które zdają się wskazywać na ich swoisty, postzależnościowy właśnie, status.

\section{WRÓG POZA GRANICAMI}

U wszystkich powieściowych postaci, które określają się jako patrioci, dostrzec można wyraźną wrogość względem obcych i skłonność do organizowania się i budowania wspólnoty w opozycji do Innego, postrzeganego jako źródło zagrożenia. Na tendencję ową spojrzeć można jako na schedę po czasach podporządkowania, w których "swoi” od „obcych" oddzielani byli w sposób jasny i niepozostawiający miejsca na domysły, zarówno w przestrzeni obowiązującego dyskursu ideologiczno-politycznego (wyraźnie wskazującego przyjaciół i wrogów systemu), jak i w obrębie kontrdyskursu, odwrotnie rozkładającego znaki wartości. Tekstem, który doskonale ukazuje, jak kolektywny wróg spaja postzależnościową narodową wspólnotę i pozwala jej na dokonanie autodefinicji jest Wojna polsko-ruska..., a głę-

\footnotetext{
${ }^{5}$ M. Janion, Zmierzch paradygmatu, w: tejże, Czy będziesz wiedziat, co przeżyłeś? Warszawa 1996.
} 
boko zakorzenione w wyobraźni zbiorowej bohaterów przekonanie o opozycyjności tego, co polskie i tego, co „ruskie” dochodzi do głosu już w tytule powieści. Wśród licznych, bardzo zresztą niespójnych, deklaracji światopoglądowych, główny bohater - Silny - wielokrotnie podkreśla, że jest patriotą. Patriotyzm Silnego nie jest jednak postawą mającą swe źródło w szczególnej miłości do wspólnoty, tradycji czy ziemi odczuwanych jako własne, lecz raczej wyrastająca z nienawiści do wszystkiego, co inne oraz do tego, co sprawia, że mężczyzna nie czuje się już „silny", lecz "słaby”, to znaczy: znieważony, zagrożony, upodrzędniony, zepchnięty na margines. Za przykład posłużyć tutaj może choćby często manifestowana przez Silnego niechęć do Zachodu raz utożsamianego z Ameryką, innym razem z Europą Zachodnią. Jednak w powieści Masłowskiej bezsprzecznie największym wrogiem każdego Polaka jest, lub powinien być, mityczny wręcz „Rusek”, miarę polskości stanowi zaś „ antyruskość”. Stosunek bohaterów Wojny... do wschodniego sąsiada charakteryzują przede wszystkim dwie postawy - głęboka podejrzliwość zrodzona ze strachu przed powrotem dawnego opresora oraz pogarda wypływająca z przeświadczenia o przewadze cywilizacyjno-kulturowej nad Rosją, której - jak przekonuje Maria Janion - od czasów romantyzmu polski dyskurs narodowy przypisywał cechy dzikości i barbarzyństwa ${ }^{6}$. Hanna Gosk zauważa, iż: „Postaci wykreowane przez Masłowską intuicyjnie uważają za »ruskie« to, co pozbawiło ich godnego miejsca w świecie i potraktowało jako gorszych" 7 . Co za tym idzie, w powieściowych realiach „ruski” ponosić musi winę za każde nieszczęście, jakie spada na Polaka - od śmierci głodowej psa Silnego po wzrost zasolenia wód Niemna. Dorastający w takiej atmosferze Silny marzy o stworzeniu narodowej przestrzeni oczyszczonej ze wszystkiego, co „ruskie”, o projekcie „Polski dla Polaków":

Ludność naszego miasta jest wtedy przy hajcu. Podpłacają likwidację Rusków z tych terenów. Przekupują urzędników do wykreślenia Rusków z listy mieszkańców, z banków danych osobowych. Dni bez Ruska to codzienność, jak i festyny, race, festiwale antyruskie, ulotki, wystrzały barwnych fajerwerków, co układają się w obwieszczenia: "Ruski do Rosji - Polacy do Polski”, „oddajcie fabryki w ręce polskich hiperrobociarzy", ,obalić siding produkcji ruskiej”, „Putin zabieraj swe krzywe dzieci”8.

Podobne postulaty padają z ust bohaterów powieści Ignacego Karpowicza. W ukazanym na kartach Niehalo środowisku patriotycznym wydzielić można trzy grupy: starsze kobiety tworzące formację "kato-polo", neonazistowskie stowarzyszenie młodzieży zbierającej się w pubie Biały Orzeł oraz grupę konserwatywnych

${ }^{6}$ M. Janion, Niesamowita Stowiańszczyzna. Fantazmaty literatury. Kraków 2007, s. 191-192.

${ }^{7} \mathrm{H}$. Gosk, Opowieści „skolonizowanego/kolonizatora”. W kręgu studiów postzależnościowych nad literaturą polską XX i XXI wieku. Kraków 2010, s. 200.

8 D. Masłowska, Wojna polsko-ruska pod flaga biato-czerwona. Warszawa 2009, s. 64. Kolejne cytaty według tego wydania lokalizuję w tekście, oznaczając symbolem WPR i numerem strony. 
publicystów skoncentrowaną wokół dziennika "Orzeł i Pogoń. W wypowiedziach reprezentantów tych grup wielokrotnie pobrzmiewa nuta ksenofobii. Przykładem mogą być tutaj komentarze staruszek przyglądających się pomnikowi księdza Popiełuszki:

Zobacz, Gienia, mówiłam, że pomnik popsuli, Żydzi; cokół niby jak się patrzy, ale ksiądz nie na cokole, tylko niżej, wstyd taki i hańba, trzeba będzie z proboszczem pogadać, tak nie można dłużej żyć9. [podkr. A.L.]

Reakcja tych samych staruszek na widok gołębi zanieczyszczających chodnik prezentuje się natomiast tak:

Taki gołąb to nie jest polski ptak, bo polskim jest orzeł, który raz dwa by tych gównojadów sprzątnął, tylko brudzą, Ukraińcy; sama powiedz, czy tak można żyć? (N, 122) [podkr. A.L.]

W powieści Karpowicza określenia takie jak „Żydzi” czy „Ukraińcy” oderwane od rzeczywistych desygnatów i pozbawione literalnego znaczenia przylgnąć mogą do każdego, kto uznany zostanie za wroga polskiego interesu, podobnie jak u Masłowskiej pojęcie „ruski” mogło zostać rozciągnięte na każdego bliżej nieokreślonego nieprzyjaciela sprawy narodowej. Zarówno „Rusek” Masłowskiej, jak i "Żyd” czy „Ukrainiec” autora Gestów spełniają funkcję Innego, paranoidalnie poszukiwanego przez byłych podporządkowanych, na którego można zrzucać winę za osobiste niepowodzenia i skierować podsycaną przez postzależnościowe resentymenty nienawiść. Innym fragmentem, który w krzywym zwierciadle ukazuje ksenofobiczność powieściowego dyskursu ojczyźnianego jest scena, w której Generałowej - ważnej postaci wykreowanego przez Karpowicza środowiska patriotycznego - podana zostaje w barze nie krajowa woda mineralna, lecz „bonaqua" - w Polsce, jak się okazuje, jedynie rozlewana. Kobieta krztusi się, zajście zostaje zinterpretowane jako sabotaż, a na kelnera-winowajcę spada kara wykluczenia ze wspólnoty narodowej, w wyniku czego:

Rozlega się donośne trzaśnięcie, jakby struna polskości w ciele kelnera została przełamana, a wraz ze złamaniem polskości jego ciało utraciło zdolność do utrzymania się w pionie. Upodlone, bo niepolskie, padło między stopy pana Pollaka a półobcasik Generałowej. - Zabrać mi to natychmiast - zakomenderowała Generałowa. - I dawać mi podlaską Krynkę. (N, 164)

Pomimo całego odrealnienia akcji Niehalo, w powieści odnaleźć można liczne sygnały silnie mocujące tekst $\mathrm{w}$ historycznych realiach jego powstania. Na kartach powieści pojawiają się między innymi takie elementy pozatekstowej rzeczywisto-

${ }^{9}$ I. Karpowicz, Niehalo. Wołowiec 2006, s. 121-122. Kolejne cytaty według tego wydania lokalizuję w tekście, oznaczając symbolem $\mathrm{N}$ i numerem strony. 
ści, jak Radio Maryja, „Nasz Dziennik” czy Młodzież Wszechpolska. Ta wielość aluzji do autentycznych instytucji czy ugrupowań wskazuje wyraźnie, iż tekst Karpowicza jest nie tylko literacką wariacją na temat tego, "co się dzieje, kiedy człowiek odkleja się od rzeczywistości, a rzeczywistość odkleja się od zdrowego rozsądku", lecz również swoistą autorską polemiką z obserwowaną, na co dzień koncepcją polityki i edukacji patriotycznej.

Nieprzejednanie właściwe patriotom Masłowskiej i Karpowicza stanowi niezbywalną cechę polskości również w ocenie Dziadka-Ojca, bohatera powieści Biato-czerwony Dawida Bieńkowskiego. Gdy w grę wchodzi obrona interesu narodowego skłonność do kompromisu i gotowość do negocjacji, szczególnie na szczeblu międzynarodowym, są - w przyjętej przezeń optyce - równoznaczne ze zdradą:

Kiedy wszyscy ci szubrawcy sprzedali się Moskalowi, Prusakowi, Austriakowi i nawet chyba Czechom! Tfu, co za obrzydliwość, nawet Czechom! I chcieli się ci zdrajcy układać, rozmawiać, szukać kompromisu. Ale my powiedzieliśmy: dość! Bóg, honor, ojczyzna! Żadnych rozmów, żadnych układów, żadnych reform! Krzyż i szabla! (BC, 19)

Mówiąc o „sprzedaniu się" „Moskalowi, Prusakowi, Austriakowi i Czechom” Dziadek nie ma na myśli żadnych wydarzeń autentycznych. Z kontekstu nie wywnioskujemy wszakże, jacy "szubrawcy” zdradzili, kiedy, w jakiej dokładnie sytuacji i kto konkretnie się temu sprzeciwił. Godny odnotowania jest tutaj jedynie fakt, iż w świadomości bohatera dochodzi do całkowitego przemieszania rozmaitych haseł z pola tematycznego "ponadnarodowe spory”, a więc nazw dawnych antagonistów, strzępków informacji o zdarzeniach historycznych oraz wzniosłych patriotycznych deklaracji. Przede wszystkim jednak, w gorączkowej wypowiedzi Dziadka-Ojca dochodzi do głosu bardzo silne przekonanie o bezwzględnym złu moralnym, jakie stanowią pertraktacje z Obcym. Przeświadczenie to ma zaś swoje źródło $\mathrm{w}$ dyskursie przeszłości - zarówno romantycznym czy wojennym, jak i tym, właściwym czasom PRL-u, w których niełatwo było przecież znieważyć i napiętnować Polaka bardziej, aniżeli nazywając go „kolaborantem”.

Jedna z czołowych postaci światowej krytyki postkolonialnej - Leela Gandhi zauważyła, iż problem nośności haseł nacjonalistycznych w państwach, które odzyskały suwerenność polityczną po latach kolonialnego czy quasi-kolonialnego ucisku, rozpatrywać można z perspektywy badań nad postzależnością. Badaczka tłumaczy, iż agresywna afirmacja tożsamości narodowej jest zjawiskiem charakterystycznym dla społeczeństw, które niedawno się uniezależniły. Jednocześnie wyraża jednak przekonanie, iż taki "kompensacyjny” nacjonalizm powinien być jedynie stanem przejściowym na drodze do odzyskania równowagi po okresie podległości. Zachowany i połączony z pielęgnowaniem urazów względem dawnego opresora staje na drodze do budowania szerszej międzynarodowej solidarności. „Najlepiej byłoby, gdyby świadomość narodowa torowała drogę etnicznie i politycznie oświe- 
conej globalnej wspólnocie"10 - podsumowuje Gandhi. Idąc za myślą badaczki, można by powiedzieć, że o ile $\mathrm{w}$ dobie zaborów, okupacji wojennej, czy nawet zależności od Związku Radzieckiego demonizacja zaborców towarzysząca uświęcaniu Polski była zrozumiałą reakcją na realnie doznawaną przemoc, zjawiskiem psychologicznie wytłumaczalnym i mającym do spełnienia określoną funkcję społeczną, o tyle praktykowana współcześnie podsyca jedynie ogień ksenofobii, uniemożliwiając Polakom przekroczenie własnych postzależnościowych niechęci oraz znacznie utrudnia wszelkie próby oczyszczenia stosunków z dawnymi oponentami. Przenosząc powyższe rozpoznania na grunt analizowanych powieści można by natomiast stwierdzić, iż wykreowane $\mathrm{w}$ nich środowiska patriotyczne nadal tkwią na etapie tworzenia "nacjonalistycznego dzieła rehabilitacji psychologicznej i kulturowej”11, które streszcza się w formule „Ruski do Rosji - Polacy do Polski”.

\section{WRÓG WEWNĄTRZ GRANIC}

Obcy pochodzący spoza granic państwa nie stanowią jedynego kontrapunktu, wobec którego organizuje się przedstawiony w powieściach dyskurs polskości. Oprócz Innych "zewnętrznych”, wrogich z etnocentrycznego punktu widzenia, we wszystkich trzech tekstach pojawiają się także Inni „wewnętrzni” - stygmatyzowani i upodrzędniani przez powieściowych patriotów, bo niemieszczący się w wyznawanej i reprezentowanej przez nich męskiej, heteroseksualnej czy katolickiej normie. Akt poniżania innych w celu wywyższenia samych siebie, tłumaczyć można jako próbę rehabilitacji własnego postzależnościowego wstydu i walki ze zinternalizowanym poczuciem drugorzędności, o czym przekonuje między innymi Hanna Gosk. Badaczka zauważa, iż „,subaltern, by zaistnieć, potrzebuje nie tylko gnębiącego opresora, którego mógłby nienawidzić i obciążać winą za własne nieszczęście oraz podrzędną pozycję [...], lecz i kogoś, kogo zdefiniuje jako gorszego, słabszego od siebie, by móc, niejako zastępczo, odreagować własną frustrację i... dowartościować się, upodmiotowić jego kosztem"12. Podobną opinię zdaje się wyrażać Przemysław Czapliński, który, komentując powieść Masłowskiej, stwierdza, że polska "matryca” wytwarzania tożsamości zakłada tworzenie hierarchii na podstawie tożsamości gorszych. „Aby mieć tożsamość, trzeba mieć wroga"13 - konkluduje badacz. Silny, bohater Wojny polsko-ruskiej..., wrogów ma bez liku. Do grona niebezpiecznych, zagrażających Innych zalicza nie tylko „proruskich" Polaków, lecz również kobiety, homoseksualistów, a także przedstawicie-

${ }^{10}$ L. Gandhi, Teoria postkolonialna. Wprowadzenie krytyczne. Tłum. J. Serwański. Poznań 2008, s. 112.

${ }^{11}$ Ibidem, s. 112.

12 H. Gosk, op. cit., s. 217.

${ }^{13}$ P. Czapliński, Polska do wymiany. Późna nowoczesność i nasze wielkie narracje. Warszawa 2009, s. 269. 
li elity intelektualnej i kapitalistów. W narracji patriotycznej przedstawionej w Niehalo prawdziwym Polakom przeciwstawieni zostają przede wszystkim euroentuzjaści i ateiści. W Biało-czerwonym zaś, podobnie jak u Masłowskiej, wrogiem Polaka-patrioty jest przede wszystkim kobieta, całkowicie niezrozumiała i nieprzewidywalna ze względu na swoją - jak przekonują bohaterowie Bieńkowskiego - całkowicie odmienną „płeć mózgu”. Wobec powyższego „duch Inności” unosić musi się również nad wszystkimi mężczyznami noszącymi cechy, które w wykładni dyskursu patriarchalnego konotują kobiecość:

I, Paweł, miękkość, przede wszystkim miękkość. O tak! Jaki to ja jestem miękki, uczuciowy i jak lubię usiąść i porozmawiać czule i delikatnie. O tak! Żadnego grubiaństwa, żadnego podniesionego głosu i porozrzucanych skarpetek. Nowoczesność, nowoczesność, nowoczesność! (BC, 25)

Mężczyźnie „nowoczesnemu” patriarchalna wspólnota charakteryzowana przez "twardość" odmawia prawa do męskości, gdyż - jak powiada Paweł - „jak się jest nowoczesnym mężczyzną, to znaczy, że nie jest się już mężczyzną" (BC, 24). A skoro - o czym przekonuje Dziadek-Ojciec - "prawdziwa Polskość to męskość, a prawdziwa męskość to Polskość" (BC, 161), to mężczyzna stając się „nowoczesnym" przestaje być nie tylko mężczyzną, ale także Polakiem. Łatwo dostrzec, iż w wątku koncentrującym się wokół postaci Dziadka-Ojca silnie uobecnia się - centralna dla tekstu Bieńkowskiego - problematyka genderowa. W patriotycznym języku karykaturowanym przez autora opowieść o tym, co publiczne i narodowe nierozerwalnie wiąże się bowiem z tym, co męskie, dyskurs ów musi więc w konsekwencji implikować patriarchalny model kultury, ograniczając rolę kobiety do troski o prywatną sferę życia. To „żołnierze i bohaterowie” pozostają synekdochicznym synonimem Polski:

Dobry Bigos tylko z rąk kobiety i Żurek dobry też z takich dłoni opiekuńczych i matczynych. Bo taka właśnie wspaniała rola przypadła naszym kobietom, żeby Żurek i Bigos dla nas warzyć, dla żołnierzy i bohaterów, żeby Bigos i Żurek warzyć dla Polski. Żeby bohaterski polski żołnierz mógł być pewien, że kobieta cierpliwie na niego czeka, myśli tylko o nim i jego trudzie i znoju, i wiernie miesza $\mathrm{w}$ garnku, i pilnuje ognia na kuchni. I kiedy bohaterski żołnierz polski miał taką pewność, że ona czeka, to on wtedy oddawał się całkowicie swojemu bohaterstwu i mógł zginąć za ojczyznę ze spokojem w duszy. (BC, s. 160-161, podkr. moje - A.L.)

\section{POLE WALKI}

Kolejną cechą łączącą patriotyczne narracje zawarte w Wojnie..., Niehalo, oraz Biało-czerwonym jest skojarzenie Polski z polem bitwy, patrioty zaś z żołnierzem lub powstańcem. Przez każdą z powieści przewijają się obrazy militarnych starć, 
we wszystkich odnaleźć można też mnóstwo passusów po brzegi wypełnionych batalistycznym słownictwem. Wydaje się, że wybór takiego właśnie obrazowania interpretować można jako, mniej lub bardziej uświadamiane, nawiązanie do tych spośród dziewiętnastowiecznych i dwudziestowiecznych narracji, które opowieść o ojczyźnie, patriotyzmie i bohaterstwie, przede wszystkim zaś o obronie tożsamości zbiorowej sytuowały właśnie w przestrzeni wojennej. Niełatwo skądinąd o stworzenie sytuacji, którą cechowałaby większa przejrzystość aksjologiczna czy znalezienie lepszego tła dla eksponowania patriotycznych uniesień i heroicznych czynów. W tekstach Masłowskiej, Karpowicza i Bieńkowskiego charakterystyczny dla tradycyjnych narracji wojennych patos znika jednak całkowicie, ustępując miejsca grotesce, karykaturze i ironii.

W prozie Masłowskiej wojna toczy się „na naszych ziemiach przy fladze białoczerwonej, [...] między rdzennymi Polakami a ruskimi złodziejami" (WPR, 38). Te fragmenty powieści, które opowiadają o konfrontacji Polaka z fantazmatycznym „ruskim” (bo, co znamienne, rzeczywisty Rosjanin nie pojawia się w tekście ani razu), najczęściej korzystają z leksyki wojennej czy okupacyjnej. W starciu z „ruskim" Polak pełni z reguły funkcję biernego obiektu padającego ofiarą obcej przemocy, aktywność zaś jest po stronie wschodniego sąsiada, któremu w udziale przypada rola agresora i najeźdźcy. „Ruscy” opisywani są jako „drapieżni zaborcy”, którzy planują założyć w Polsce: „państwo ruskie, może nawet białoruskie, chcą pozamykać szkoły, urzędy, zabić w szpitalach polskie noworodki, by wyeliminować je ze społeczeństwa” (WPR, 38) oraz zamierzają "robić pomiary pod przyszłe wysiedlenia Polaków, pod grabienie polskich domostw." (WPR, 157) Nie dziwi, że majak z pogranicza jawy i snu dopadający Silnego, który, trzeźwiejąc, dostrzega nieład w swoim mieszkaniu, przybiera następujący kształt:

A kiedy tak stoję, przede mną widok na całe mieszkanie utrzymany w stylistyce batalistycznej, krajobraz po bitwie. Zastanawiam się, czy przypadkiem wojna już się nie stała tu pod moją nieobecność, kiedy spałem, decydująca bitwa, samo centrum dowodzenia. Gdy spałem, Ruski weszli na mieszkanie, wdarli się. Wszystko powywracali kolbami, pozestrzelali z obrazów pejzaże z wodospadami, słoneczniki, a szczególnie zniszczyli zegar skórzany. Matkę Boską z Lichenia z błękitnego plastiku strącili z lodówki, łebek odleciał, święta woda nabrudziła na posadzkę. Zadeptali kafelki w łazience. Wszystkie kobiety, co się dało, zgwałcili tu na wersalce, urządzili tu sobie sztab generalny, komitet do spraw przeleceń. Konie wprowadzili, ptasie mleczko wyjedli, papierosy spalili, tapicerkę zasyfili i do widzenia, do zobaczenia w przyszłym życiu na Białorusi. Mojego brackiego i mą starszą wzięli na niewolników. Mnie pewnie zabili [...]. (WPR, 77)

Obraz skonstruowany przez Masłowską w oczywisty sposób karmi się rozmaitymi opowieściami o rosyjskiej agresji utrwalonymi $\mathrm{w}$ narodowej metanarracji Polaków. Można w nim dostrzec nawet - zamierzone lub nie - podobieństwo do sceny najazdu Moskali rozpoczynającej IX księgę Pana Tadeusza. Silny i jego rówie- 
śnicy nie doznali bezpośredniej przemocy ze strony Rosji, po poprzednich pokoleniach odziedziczyli jednak pewien gotowy zbiór metafor, "słownik”, jak powiedziałby Richard Rorty ${ }^{14}$, służący do opowiadania o relacjach polsko-rosyjskich. Tekst Masłowskiej zdaje się ukazywać, iż język ten, pomimo zmiany historycznych realiów, wykazuje trwałość - w wyniku czego „wojna polsko-ruska” wiedzie swój pośmiertny żywot $\mathrm{w}$ przestrzeni polskiego postzależnościowego dyskursu tożsamości, a młodzi Polacy nadal cierpią na - posługując się określeniem samej autorki - „zbiorową halucynację względem walk z wyimaginowanym wrogiem”. (WPR, 190)

Zaborczą siłą, przeciwko której decydują się wystąpić zbrojnie patrioci Karpowicza nie jest Rosja, lecz Unia Europejska. O wydarzeniu, jakie niebawem rozpęta prawdziwą „wojnę polsko-europejską" jeden z młodych nacjonalistów opowiada zaś następująco:

Za cztery godziny przed Ratuszem spotka się komisarz Unii Europejskiej z prezydentem Białegostoku, a właściwie $\mathrm{z}$ wice. Podpiszą ostatecznie Konstytucję europejską, w której nie ma Boga i nie ma Polski. Jest tylko wstyd i hańba. Spisek i zdrada. Koniec Ojczyzny i Czwarty Rozbiór. (N, 164)

Biorąc pod uwagę fakt, iż powieść Niehalo ukazała się w roku 2006, czyli zaledwie dwa lata po przystąpieniu Polski do Unii Europejskiej, podejrzewać można, iż pisząc te słowa Karpowicz bezpośrednio nawiązywał do głosów dobiegających ze środowisk przeciwnych europejskiej integracji, postrzeganej jako zagrożenie dla tradycyjnych wartości narodowych i katolickich („nie ma Boga i nie ma Polski”) oraz utożsamianej z dobrowolnym wikłaniem się w kolejną relację o charakterze zależnościowym ("Czwarty Rozbiór"). Postaci Karpowicza, tak samo zresztą, jak te z powieści Masłowskiej i Bieńkowskiego, jako modelowi dawni podporządkowani, swoich racji dowodzić potrafią jedynie przy pomocy agresji. Nie zaskakuje więc, że chcąc powstrzymać zbliżające się zagrożenie, uruchamiają mechanizmy sprzeciwu znane z przeszłości i decydują się na zryw narodowowyzwoleńczy. W nazwach oddziałów mających walczyć o niepodległość odzwierciedlenie znajdują największe mity i traumy narodowe. Mamy legiony: „Kościuszkowski”, „Mickiewiczowski”, ,Zdrady Jałtańskiej”, "Chwały Rejtana”, ,Mordu Katyńskiego", „Powstańców Warszawy” oraz „Czystek Stalinowskich”. Na pomoc owym oddziałom gotowe są ponadto wyruszyć "płaczki bojowe”, atakujące przeciwnika zmasowanym lamentem:

- Za wóz Drzymały i cierpienie dzieci we Wrześni - łkają. Za miecza cięcia Jasnogórskiego Obrazu - zawodzą. Z pergaminowych twarzy skapują kwasowe łzy. Wybuchają one ze skwierczeniem rozgrzanej oliwy [...]. Słowa płaczek godzą w olbrzymów

${ }^{14}$ Zob. R. Rorty, Przygodność, ironia i solidarność. Przeł. W. J. Popławski. Warszawa 2009. 
o gwiaździstej piersi. Trafieni wrześnią bądź maksymilianem kolbe drgają w niemal dowcipnej epilepsji jakby uderzeni ładunkiem elektrycznym. (N, 195)

Tworząc taki obraz polskich sił powstańczych Karpowicz podnosi, znany już skądinąd doskonale polskiemu dyskursowi literackiemu, temat krytyki narodowego kultu martyrologii. Romantyczny mesjanizm uświęcający porażkę oraz obdarzający cierpienie sensem teleologicznym, potępiany już u swego zarania przez nawołującego do „uniepotrzebnienia męczeństwa” Norwida, w odbiorze współczesnych autorów jawi się jako tradycja jałowa, niezrozumiała i całkowicie bezproduktywna. Narrator Niehalo stwierdza wprost:

Pomniki nigdy nie wyrastały za rzeczywiste dokonania, tylko za interpretację życia w kontekście śmierci, najlepiej bohaterskiej i tragicznej [...]. W ogóle, co to za pomysł, żeby czyjąś śmierć nagradzać płytą nagrobną albo erekcją czegoś kamiennego? Jak nie pojmuję - czyjaś śmierć może prowadzić do lepszego? $(\mathrm{N}, 60)$

Romantyczna tendencja do uszlachetniania klęski w imię dewizy „Gloria victis!" przywołana zostaje również przez Dawida Bieńkowskiego:

[...] nigdy w żadnej walce nie chodziło nam przecież o zwycięstwo militarne. Nam zawsze chodzi o zwycięstwo moralne. (BC, 277)

Słowa te wypowiada Dziadek-Ojciec - postać nosząca wiele mówiący przydomek „Pułkownik Parada” oraz stanowiąca uosobienie patriotyzmu łączącego się z etosem żołnierskim i sarmackim umiłowaniem wojaczki. Dziadek-Ojciec jest jak zapewnia jego syn i wnuk w jednej osobie - „żywą historią Polski”, , "prawdziwym pułkownikiem, wielokrotnym powstańcem, kawalerzystą i bohaterem” (BC, 17), jego wojenne doświadczenie skupia zaś wszystkie najważniejsze i najsilniej zakotwiczone w zbiorowej świadomości wydarzenia militarne w dziejach kraju od bitwy pod Grunwaldem po Powstanie Warszawskie. Przytoczony powyżej cytat poświadcza żywione przez Dziadka-Ojca przekonanie, iż od realnych szans powodzenia heroicznych zrywów narodowowyzwoleńczych ważniejsze jest samo piękno niezłomnej postawy prometejskiej. „Im większa przewaga wroga, tym szybciej rozkaz przechodzi do historii, a chłopcy z większym zapałem idą w bój” (BC, 155) - zapewnia. Nietrudno zauważyć, że w Biało-czerwonym Bieńkowski kontynuuje podjęty przez Witolda Gombrowicza na kartach Trans-Atlantyku rozrachunek z tradycją patriotyczną, przymuszającą każdego Polaka do przedkładania interesów narodowych nad indywidualne i nakładającą nań obowiązek "służenia sprawie". Jak Gombrowiczowski Związek Kawalerów Ostrogi ilustrować ma bezproduktywność rytuału samodoskonalenia się poprzez cierpiętnictwo, tak urządzane przez Ojca-Dziadka (również noszącego ostrogi) uliczne walki, podczas których dowodzi gromadą okolicznych dzieci, obnażają śmieszność rządzącego starcem patriotycznego imperatywu walki o ojczyznę, której nic nie zagraża. O ile 
bowiem bohaterowie Masłowskiej walczyli przeciwko wyimaginowanemu „ruskiemu", a patrioci Karpowicza wypowiadali wojnę euroentuzjastom, o tyle Pułkownik Parada wyrusza w swój paranoidalny bój pomimo braku jakiegokolwiek nieprzyjaciela. Kulminacyjnym punktem militarnych przedsięwzięć Dziadka-Ojca jest karykaturalna akcja szturmowania trzepaka, w której nieomal ginie syn głównego bohatera. Chłopiec nie rozumiejąc, dlaczego własny Dziadek naraził go na niebezpieczeństwo, wydając rozkaz do niczemu niesłużącej walki, usłyszy jedynie, że słuszności rozkazu nie należy oceniać. „Wolno go tylko czcić. Tak jak czci się ojca swego..." (BC, 276) Upomniany zostanie ponadto, iż powinien cieszyć się z poniesionych obrażeń, gdyż "mężczyźnie, mężczyźnie Polakowi najbardziej do twarzy ze śmiercią. [...] A kobiecie Polce we Łzach i w czerni jest najlepiej". $(B C, 279)$

\section{MEGALOMANIA NARODOWA}

We wszystkich omawianych tekstach dostrzec można, słabiej lub mocniej akcentowany, problem megalomanii narodowej, jaka towarzyszy reprezentowanej przez bohaterów Masłowskiej, Karpowicza i Bieńkowskiego wersji patriotyzmu. W Wojnie polsko-ruskiej i Niehalo daje o sobie znać przekonanie o przewadze Polski zarówno nad Zachodem - pod względem moralnym, jak i nad Wschodem - pod względem cywilizacyjnym. W Biato-czerwonym fundamentem polskości uczyniony zostaje natomiast mit sarmacki, którego niezbywalną częścią jest przeświadczenie o wyjątkowości Polski i sile jej pozycji na arenie międzynarodowej. „Jakże inne narody powinny podziwiać nas i być nam wdzięczne. [...] Nie ma takiego drugiego Narodu!" (BC, 158-159) - zapewnia swoich rozmówców bohater Bieńkowskiego. Wydaje się, że pobrzmiewająca nierzadko w postzależnościowych narracjach patriotycznych nostalgia za dawną świetnością I Rzeczpospolitej oraz doszukiwanie się „rdzenia” polskości w czasach jagiellońskich mogą być interpretowane jako kolejny sposób rekompensaty rozczarowania aktualną sytuacją kraju i doraźny lek na poczucie degradacji wywołane doświadczeniem quasi-kolonialnym. Innymi słowy, snucie z dzisiejszej perspektywy opowieści odwołujących się do mitu Polski „od morza do morza”, można by interpretować jako wytwarzanie tego, co Homi Bhabha nazwał necessary fictions, a Ewa Thompson przetłumaczyła jako „konieczne wymysły" 15 .

Podsumowując, na narracje patriotyczne snute przez bohaterów Masłowskiej, Karpowicza i Bieńkowskiego spojrzeć można jako na opowieści byłych subalternów, którzy, pomimo suwerennej ojczyzny, nie potrafią przezwyciężyć postzależ-

${ }^{15}$ E. M. Thompson, Said a sprawa polska. Przeciwko kulturowej bezsilności peryferii. „Europa. Tygodnik Idei" 2005, nr 26 (29.06.2005). 
nościowych ograniczeń i resentymentów, modelujących w dalszym ciągu ich stosunek do „swoich” i „obcych” oraz organizujących tożsamościowy dyskurs narodowej wspólnoty. Zauważyć warto również, że w przestrzeni omówionych powieści język patriotyczny jawi się jako skostniały i niepoddający się modyfikacjom, język, do którego można się co najwyżej ustosunkować - przyjąć za swój własny lub całkowicie odrzucić. W konsekwencji, tym postaciom Masłowskiej, Karpowicza i Bieńkowskiego, które nie czują się rzecznikami patriotyzmu reprezentowanego przez Silnego, Dziadka-Ojca lub formację "kato-polo”, towarzyszyć musi frustracja i chęć, jak to określiła Maria Janion, „pożegnania się z Polską"16. Warto zastanowić się nad tym, co decyduje, iż omówione literackie reprezentacje patriotyzmu, a także przedstawienia im podobne, których nie brakuje wszakże w polskiej prozie ostatnich lat, korzystają ze zbliżonych schematów, uaktualniając jednocześnie przywoływane stereotypy. Wiele wskazuje na to, że na owo zjawisko spojrzeć można jako na literackie polemiki z uobecniającą się we współczesnym dyskursie politycznym retoryką bogoojczyźnianą. Wydaje się bowiem, iż w ocenie autorów język patriotyczny, w swojej rewindykacyjnej, agresywnej odsłonie, zawłaszczony został przez określone środowiska polityczne, które nadały mu rangę jedynego autentycznego i uprawnionego sposobu artykułowania polskości. Możliwe, że właśnie z tego powodu w analizowanych tekstach Masłowskiej, Karpowicza i Bieńkowskiego pojęcia takie, jak patriotyzm czy naród intuicyjnie łączone są z bezkompromisowością, ksenofobią, aprobatą dla konserwatywnego katolicyzmu czy patriarchalnego modelu kultury. Dominujący dyskurs ojczyźniany ukazywany jest zaś jako koturnowy, zamrożony w anachronicznej, romantycznej formie i w odczuciu młodego pokolenia - niekomunikatywny. Głębszego namysłu wymagałby zapewne również fakt, iż krytyce dominującego dyskursu ojczyźnianego podejmowanej przez omawiane powieści nie towarzyszy żadna próba stworzenia „pozytywnej” wersji patriotyzmu. Za gestem negacji nie podąża propozycja, która przemawiałby do tych, którzy nie podzielają konserwatywnego wyobrażenia o postawie patriotycznej. Jeżeli więc uznać literaturę za pewne, specyficzne, co prawda, ale jednak, źródło wiedzy o społeczeństwie, to trzeba przyznać, iż u przywoływanych autorów nie widać literackiej reprezentacji dla - obecnego przecież w rzeczywistej przestrzeni społecznej - patriotyzmu, którego rzecznikami byli chociażby Józef Czapski czy Jerzy Giedroyć, a o którym Jan Józef Lipski pisał, iż jest „z miłości - i do miłości ma prowadzić, jakakolwiek inna jego forma jest [bowiem] deformacją etyczną"17.

${ }^{16}$ M. Janion, Niesamowita Stowiańszczyzna, op. cit., s. 304.

17 J. J. Lipski, Dwie ojczyzny, dwa patriotyzmy (uwagi o megalomanii narodowej i ksenofobii Polaków), w: Tunika Nessosa. Warszawa 1992, s. 140. 